\title{
Physiochemical and functional properties of albumin and globulin from amadumbe (Colocasia esculenta) corms
}

\author{
Rudean HILARY VAN WYK ${ }^{1}$ (D), Eric OSCAR AMONSOU ${ }^{1 *}$
}

\begin{abstract}
Amadumbe (Colocasia esculenta), commonly known as Taro is an indigenous underutilised crop of Southern Africa. Limited utilisation of amadumbe grown in the region may be attributed to the lack of enough information on its corms and storage proteins. In this study, albumin, and globulin fractions from three landraces were investigated for their physicochemical and functional properties. Crude protein contents of amadumbe flours ranged between 2-4\%. Amadumbe flours were rich in lysine $(5.3 \mathrm{~g} / 100 \mathrm{~g})$ and leucine $(9.1 \mathrm{~g} / 100 \mathrm{~g})$. Three major protein families were identified corresponding to albumin and globulin with approximately $55-60 \mathrm{kDa}, 20-22 \mathrm{kDa}$ and $14 \mathrm{kDa}$, respectively. FTIR revealed a protein secondary structure dominated by $\beta$-sheets and $\beta$-turns. Intrinsic fluorescence results suggested that all albumin and globulin fractions had well-defined tertiary structures. The protein solubility of albumin and globulin fractions were minimal at $\mathrm{pH} 5$. Hydrophobicity data seemed to correlate with emulsification behaviour of the protein fractions. Amadumbe proteins and its albumin and globulin fractions can be a promising source for food protein applications.
\end{abstract}

Keywords: characterisation, amadumbe; taro protein; composition; structure.

Practical Application: Proteins from amadumbe have not gained significant attention to unlock its potential for new food product development. Therefore, amadumbe albumin and globulin fractions could be a good source of protein ingredient for food processing applications and nutraceutical ingredients, meanwhile supplying valuable information for the growth and utilisation of amadumbe in South Africa.

\section{Introduction}

Currently, with the world population rising and limited resources such as cultivable land and fresh water there is a significant requirement for alternative food sources to meet global requirements for various applications (Costa et al., 2020; Nascimento et al., 2020). Taro is commonly known as amadumbe (Colocasia esculenta) in the Province of KwaZulu-Natal, South Africa and is recognized as an indigenous crop. Amadumbe belongs to the monocotyledonous family Araceae, sub-family Aroideae with a storage organ being a tuberous underground corm. Over $80 \%$ of the proteins in tubers are storage proteins and they have been found to play a substantial role in food functionality (Pereira et al., 2018).

Amadumbe corm is a good source of starch and contains a certain level of protein depending on environmental conditions, variety, and maturity of the harvest. The protein content of amadumbe could vary between 5-12\% (Mawoyo et al., 2017). Amadumbe protein is rich in essential amino acids such as phenylalanine, leucine, lysine, and methionine compared to potato (Ju et al., 2017). Amadumbe corms have four major storage protein families consisting of two albumins known as A1 (molecular weight of 12-14 kDa) and A2 (55-66 kDa) and two globulins, G1 (14 kDa) and G2 (22 kDa) (Pereira et al., 2014). Although, the protein composition of amadumbe was identified, little information is available on the intrinsic physiochemical characteristics of amadumbe albumin and globulin fractions such as emulsification, fluorescence, surface hydrophobicity and protein solubility. Protein-based functional properties, such as emulsification and protein solubility are influenced by important factors such as $\mathrm{pH}$, surface hydrophobicity, protein molecular structure and size. For instance, Adebiyi \& Aluko (2011) found that the highest level of protein solubility of pea globulins was attained above $\mathrm{pH} 6$ and below $\mathrm{pH}$ 4. Globulin fractions in hemp seeds contained higher aromatic and hydrophobic residues than the albumin fraction, but higher solubility and foaming ability was reported for the albumin fraction than the globulin fraction (Malomo \& Aluko, 2015).

Amadumbe flour and proteins have not gained significant attention to unlock the corms potential for industrial food applications. With improved accessibility and research information, the utilisation of amadumbe could be expanded. For instance, starch could be extracted from taro corms for industrial application and new uses may be found for the storage protein by-product. This will lead to reduced wastage and maximising profitability around amadumbe. Therefore, the aim of this study is to characterise the albumin and globulin fractions of amadumbe storage proteins. 


\section{Materials and methods}

\subsection{Materials}

Three amadumbe (Colocasia esculenta var. esculenta) landraces were used for this study. A small corm with white flesh (SCW), small corm with purple flesh (SCP) and a large corm with purple flesh (LCP) (Fig. S1, Supplementary material) were obtained from Jozini in Durban, KwaZulu-Natal province, South Africa. Corms were washed and stored in a cool and dry place until further use. Acrylamide, bisacrylamide, sodium dodecyl sulfate (SDS); 1-anilino-8-naphthalene sulfonate (ANS), N,N,N,N-tetramethyl-Ethylenediamine (TEMED); ammonium persulfate (APS); Coomassie Brilliant Blue G-250; thiourea; urea; dithiothreitol (DTT); iodoacetaminde; protein marker, Tris, EDTA, methanol, n-hexane, 2-mercaptoethanol (2-ME), trichloroacetic acid (TCA), potassium bromide, sodium hydroxide, hydrochloric acid, ciproflaxin, acetone and glycerol were obtained from Sigma-Aldrich (St. Louis, MO, USA). Chemicals and solvents used were of laboratory grade.

\subsection{Preparation of amadumbe flour}

Amadumbe flours were prepared as indicated by the technique proposed by Tattiyakul et al. (2006) with slight adjustments. Freshly harvested amadumbe corms were peeled, rinsed and cut into a width of $3 \mathrm{~mm}$. Corm slices were dried in a hot air oven (D-37520, Thermo Fisher Scientific, Germany) at $40{ }^{\circ} \mathrm{C}$ for 24-48 h. Dried amadumbe slices were milled into a flour and sieved using a $180 \mu \mathrm{m}$ test sieve to obtain fine flour. The flours were retained at $4{ }^{\circ} \mathrm{C}$ until further analysis.

\subsection{Proximate analysis of amadumbe flour}

Amadumbe flours were analysed for moisture, ash and crude fat contents following Association of Official Analytical Chemists (2000) standard methods. Total protein ( $\mathrm{N}$ x 6.25) content was resolved utilising the Kjeldahl technique and total carbohydrate was calculated by the difference.

\subsection{Amino acid profile of amadumbe protein}

The amino acid profiles of amadumbe flours were resolved by the Pico-Tag method (Bidlingmeyer et al., 1984).

\subsection{Albumin and globulin protein extraction}

Proteins were extracted following the method depicted by Carneiro et al. (1990) with minor changes except that the extraction were performed at $40^{\circ} \mathrm{C}$ for $1 \mathrm{~h}$ using $0.05 \mathrm{M}$ sodium phosphate buffer ( $\mathrm{pH} 8$ ) containing $0.5 \mathrm{M} \mathrm{NaCl}$ (ratio: $1 \mathrm{~g}$ flour to $5 \mathrm{ml}$ ). The extracted albumins and globulins were stored at $-20{ }^{\circ} \mathrm{C}$. Bradford method was used to establish the protein concentrations (Bradford, 1976). The albumin and globulin yield were resolved as the dry mass of protein isolate (Arise et al., 2015).

\subsection{Analysis of Sodium dodecyl sulfate-polyacrylamide gel electrophoresis (SDS-PAGE)}

SDS-PAGE examination of extracted proteins were done utilising the procedure depicted by Laemmli (1970) with a $4 \%$ stacking gel and a $12 \%$ separating gel. Fifteen microgram protein was prepared and loaded onto the gels. Coomassie Brilliant Blue G-250 stain (0.25\%) was used to stain the gels. Molecular masses of the polypeptide bands were assessed and contrasted with the standard protein marker (PageRuler Unstained Protein Ladder, Thermo Scientific).

\section{FTIR}

FTIR spectra of amadumbe protein extracts were obtained using an FTIR spectrometer (Varian 800, Scimitor Series, CA, USA). Measurements were done in the mid-infrared region at a percentage transmittance mode from $4000-400 \mathrm{~cm}^{-1}$ and read from 32 cycles (Long et al., 2015).

\section{Surface Hydrophobicity}

Surface hydrophobicity of protein isolates were resolved utilising a hydrophobic fluorescence probe, 1-anilino-8naphthalene sulfonate (ANS) with slight alterations (Hayakawa $\&$ Nakai, 1985). Serial dilutions of the protein solutions (1\%) ranging from $0.0025-0.015 \%(\mathrm{w} / \mathrm{v})$ were performed in $0.01 \mathrm{M}$ phosphate buffer ( $\mathrm{pH} 7.0)$. Twenty microliters of ANS $(8.0 \mathrm{mM}$ in $0.1 \mathrm{M}$ phosphate buffer, $\mathrm{pH} 7.0$ ) were transferred to $4 \mathrm{ml}$ of protein solution. The fluorescence intensity was estimated with a fluorescence spectrophotometer (Varian, Cary eclipse, Agilent, CA, USA) at the excitation and emission frequency of 390 and $470 \mathrm{~nm}$, individually.

\section{Intrinsic fluorescence spectra}

Protein solutions ( $1 \mathrm{mg} / \mathrm{ml}$ in $0.1 \mathrm{M}$ phosphate buffer, $\mathrm{pH} 7.0$ ) were measured with a fluorescence spectrophotometer (Varian, Cary eclipse, Agilent, CA, USA). The excitation wavelength was $275 \mathrm{~nm}$, while the emission spectra were documented in the range of 280-500 $\mathrm{nm}$. Final fluorescence emission spectrum of the albumin and globulin solutions were obtained by subtraction of the buffer emission spectrum. The method used were depicted by Li et al. (2013) with minor alterations.

\section{Protein solubility}

The $\mathrm{pH}$ solubility profiles were resolved utilising the technique by Adebiyi \& Aluko (2011) with slight amendments. Albumin and globulin solutions $(10 \mathrm{mg} / \mathrm{ml}$ in ultrapure water) were adapted to $\mathrm{pH} 3,4,5,7,8$ and 9 in $0.01 \mathrm{M}$ phosphate buffer with either $1 \mathrm{M} \mathrm{HCI}$ or $1 \mathrm{M} \mathrm{NaOH}$. Total protein $(10 \mathrm{mg} / \mathrm{ml})$ was dispersed in $0.1 \mathrm{M} \mathrm{NaOH}$. The protein suspension was vortex for $2 \mathrm{~min}$ and centrifuged at $10000 \mathrm{~g}$ for $20 \mathrm{~min}$. Protein concentrations of the supernatants were established using the Bradford (1976) technique.

Protein solubility was calculated (Adebiyi \& Aluko, 2011) as Equation 1:

$$
\% \text { solubility }=\frac{\text { protein concentration }}{\text { total protein concentration }} \mathrm{X} 100
$$

\section{Emulsifying properties}

Emulsifying activity (EA) and stability were resolved utilising the technique of Neto et al. (2001) with slight alterations. Two 
millilitre protein solutions $(1 \% \mathrm{w} / \mathrm{v})$ were mixed with $2 \mathrm{ml}$ canola oil. Dispersions were magnetically stirred at room temperature for $1 \mathrm{~min}$ and centrifuged at $1100 \mathrm{~g}$ for $5 \mathrm{~min}$.

The EA was calculated according to Neto et al., 2001, as Equation 2:

$\mathrm{EA}=\frac{\text { Height of emulsified layer in the tube }}{\text { Height of the total content in the tube }} \times 100$

Emulsion stability (ES) was measured by warming the emulsion at $80{ }^{\circ} \mathrm{C}$ for $30 \mathrm{~min}$ prior to centrifuging at $1100 \mathrm{~g}$ for $5 \mathrm{~min}$.

The ES was calculated according to Neto et al., 2001, as Equation 3:

$\mathrm{ES}=\frac{\text { Height of emulsified layer after heating }}{\text { Height of the emulsified layer before heating }} \mathrm{X} 100$

\section{Statistical analysis}

Protein sample preparation and physiochemical analysis were completed in sets of three where needed. One-way analysis of variance (ANOVA) was used for statistical analysis of the data. Means were assessed utilising the Fisher Least Significant Difference (LSD) test $(\mathrm{p}<0.05)$.

\section{Results and discussion}

\subsection{Amadumbe flour composition}

The proximate composition of amadumbe landraces is given in Table 1 . The percentage crude protein varied with the highest of $4.4 \%$ and the least of $2.3 \%$, respectively. The data is in agreement with Mawoyo et al. (2017). Though, relatively low protein content has been observed in this study, previous studies reported higher protein contents of up to $11 \%$, which is slightly more compared to other tuber harvests such as cassava, yam and sweet potato (Chandrasekara \& Kumar, 2016). The carbohydrate contents for all three landraces were high, thus signifies that amadumbe is a rich source of energy which could be used for human nutrition. These findings are in accordance with Alcantara et al. (2013) of amadumbe flour.

The ash represents another important component in amadumbe flour with values ranging between $2.0-11 \%$. The high ash values

Table 1. Proximate composition on dry matter (\%) of amadumbe landraces*.

\begin{tabular}{|c|c|c|c|}
\hline \multicolumn{4}{|c|}{ Landrace } \\
\hline \multirow{2}{*}{ Constituents } & $\begin{array}{l}\text { Small Corm } \\
\text { White flesh }\end{array}$ & $\begin{array}{l}\text { Small Corm } \\
\text { Purple flesh }\end{array}$ & $\begin{array}{l}\text { Large Corm } \\
\text { Purple flesh }\end{array}$ \\
\hline & (SCW) & (SCP) & (LCP) \\
\hline Protein & $4.4 \pm 0.10^{\mathrm{a}}$ & $4.2 \pm 0.23^{\mathrm{a}}$ & $2.3 \pm 0.20^{\mathrm{b}}$ \\
\hline Moisture & $6.4 \pm 0.33^{\mathrm{a}}$ & $8.7 \pm 0.12^{\mathrm{bc}}$ & $8.3 \pm 0.50^{c}$ \\
\hline Ash & $11.1 \pm 0.56^{\mathrm{a}}$ & $7.4 \pm 0.30^{\mathrm{b}}$ & $2.0 \pm 0.78^{c}$ \\
\hline Fat & $0.9 \pm 0.45^{\mathrm{a}}$ & $0.4 \pm 0.05^{\mathrm{a}}$ & $0.1 \pm 0.24^{\mathrm{a}}$ \\
\hline $\begin{array}{l}\text { Total } \\
\text { Carbohydrate }\end{array}$ & $77.2 \pm 0.15^{\mathrm{a}}$ & $79.3 \pm 0.64^{\mathrm{b}}$ & $87.3 \pm 0.07^{c}$ \\
\hline
\end{tabular}

Mean \pm SD values are reported; ${ }^{\star}$ Letters that are dissimilar in a row are significantly different $(\mathrm{p}<0.05) ;{ }^{*}$ Total Carbohydrates by difference. in this study could be an indication of high mineral contents in amadumbe corms. The low ash content observed could also be attributed to high water levels present in the large amadumbe corms. The fat content ranged between $0.1-0.9 \%$. Fat contents in amadumbe corms are generally low and these results followed similar trends as reported for amadumbe cultivars (Mawoyo et al., 2017).

The protein contents of amadumbe-based food can be improved by consuming amadumbe together with other high protein sources for good sustenance. Due to its high carbohydrates, amadumbe corms can be considered as a food security crop, especially for people living in areas where amadumbe is produced in large quantities. Additionally, the differences in nutritional composition in amadumbe crops may also be attributed to environmental factors and agronomic practices (Tattiyakul et al., 2006).

\subsection{Amino acid profile of amadumbe protein}

Aspartic and Glutamic acid were the major amino acids followed by leucine (Table 2). However, the aspartic acid content of SCW was significantly lower $(\mathrm{p}<0.05)$ than in SCP and LCP. These findings are in accordance with Mbofung et al. (2006) who reported aspartic and glutamic acid to be the highest abundant amino acids followed by leucine in amadumbe flour. In addition, amadumbe were moderately rich in essential amino acids compared to potato and sweet potato (Ju et al., 2017). Based on the Food and Agriculture Organisation (2007) reference, amadumbe fulfilled or exceeded the adequate requirements of essential amino acids needed. Specifically, lysine, leucine, phenylalanine, valine, threonine and isoleucine. It is especially important to have a diet high in leucine as it stimulates protein synthesis in muscles. Therefore, amadumbe offer some important nutritional characteristics making amadumbe a good supplement to cereals and protein beverages that are lacking in essential amino acids.

\subsection{Albumin and globulin protein yield}

Protein yield is the measure of protein that can be gained from a known amount of crude sample which is vital for technology implementation and commercialisation. A high yield offers a superior cost proportion which improves the effectiveness of protein productions. The protein yields of SCW, SCP and LCP globulin $(58.5 \%, 56.6 \%$ and $60.8 \%)$ were significantly $(\mathrm{p}<0.05)$ higher than those of albumin (45.6\%, 47.6\% and 52.1\%) fractions (Table S1, Supplementary material). This indicates that the globulin fractions are the abundant protein. Pereira et al. (2018) reported that amadumbe globulins are the most abundant and accounts for $80 \%$ of total soluble proteins in the corms. These results compare favourably with other tuber crops such as potato, sweet potato, and yam (Shewry, 2003).

\subsection{SDS-PAGE}

The amadumbe corms from landraces SCW, SCP and LCP were analysed by SDS-PAGE. Protein bands approximately 55-60 kDa, 20-22 kDa and $14 \mathrm{kDa}$ were visualised (Figure 1). The protein fractions comprised of five polypeptide bands corresponding to three of the four major protein families reported by Pereira et al. (2014). 
Table 2. Amino acid profile (g/100 g protein) of amadumbe flour.

\begin{tabular}{|c|c|c|c|c|c|}
\hline \multicolumn{6}{|c|}{ Landrace } \\
\hline \multirow{3}{*}{ Amino acid (AA) } & Small Corm & Small Corm & Large Corm & \multicolumn{2}{|c|}{ FAO/WHO/UNU } \\
\hline & White flesh & Purple flesh & Purple flesh & \multirow{2}{*}{ Children } & \multirow{2}{*}{ Adults } \\
\hline & $(\mathrm{SCW})$ & (SCP) & (LCP) & & \\
\hline Isoleucine & $4.0 \pm 0.10$ & $3.5 \pm 0.10$ & $3.5 \pm 0.10$ & 3.1 & 1.3 \\
\hline Leucine & $10.1 \pm 0.10$ & $8.9 \pm 0.10$ & $8.4 \pm 0.10$ & 6.3 & 1.9 \\
\hline Lysine & $5.4 \pm 0.10$ & $5.1 \pm 0.10$ & $5.3 \pm 0.10$ & 5.2 & 1.6 \\
\hline Phenylalanine & $7.1 \pm 0.10$ & $6.1 \pm 0.10$ & $6.0 \pm 0.10$ & 4.6 & 1.9 \\
\hline Threonine & $5.3 \pm 0.10$ & $4.6 \pm 0.10$ & $4.4 \pm 0.10$ & 2.7 & 0.9 \\
\hline Valine & $6.2 \pm 0.10$ & $5.2 \pm 0.10$ & $5.3 \pm 0.10$ & 4.2 & 1.5 \\
\hline Histidine & $2.7 \pm 0.10$ & $2.5 \pm 0.10$ & $2.2 \pm 0.10$ & 1.8 & 1.6 \\
\hline Glutamic acid & $12.5 \pm 0.10$ & $11.8 \pm 0.10$ & $13.5 \pm 0.10$ & & \\
\hline Arginine & $7.7 \pm 0.10$ & $6.8 \pm 0.10$ & $6.4 \pm 0.10$ & & \\
\hline Tyrosine & $4.5 \pm 0.10$ & $3.9 \pm 0.10$ & $2.8 \pm 0.10$ & & \\
\hline Alanine & $5.4 \pm 0.10$ & $5.5 \pm 0.10$ & $5.7 \pm 0.10$ & & \\
\hline Aspartic acid & $6.9 \pm 0.10$ & $14.6 \pm 0.10$ & $14.4 \pm 0.10$ & & \\
\hline Serine & $7.3 \pm 0.10$ & $6.5 \pm 0.10$ & $7.1 \pm 0.10$ & & \\
\hline Glycine & $6.4 \pm 0.10$ & $5.8 \pm 0.10$ & $5.7 \pm 0.10$ & & \\
\hline Proline & $5.2 \pm 0.10$ & $4.7 \pm 0.10$ & $4.8 \pm 0.10$ & & \\
\hline
\end{tabular}

Recalculation has been made where needed; Food and Agriculture Organisation (2007) recommended pattern of essential amino acids requirement for adults and children of 2-5 years; Mean \pm SD values are reported.

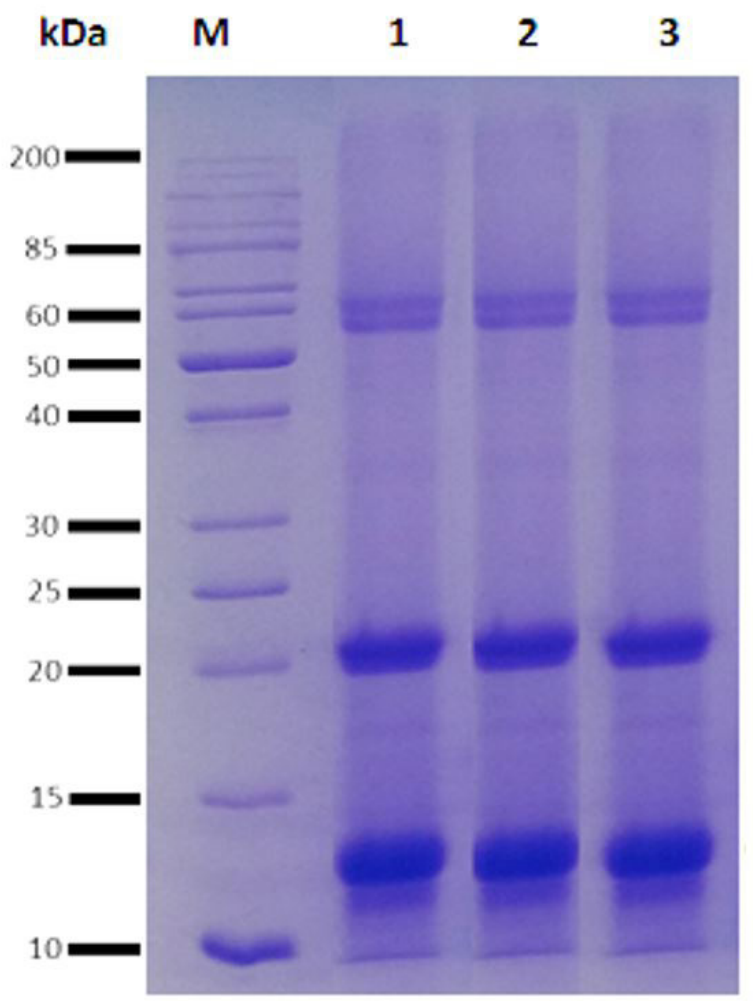

Figure 1. SDS-PAGE analysis of extracted amadumbe protein fractions. (1) Small Corm with White flesh (SCW); (2) Small Corm with Purple flesh (SCP); (3) Large Corm with Purple flesh (LCP).

The four major protein families reported includes two albumins A1 (12-14 kDa) and A2 (55-66 kDa); and two globulins G1 $(14 \mathrm{kDa})$ and G2 (22 kDa). In amadumbe the G2 globulin family is also reported to contain two polypeptide protein bands, G2a (24 kDa) and G2b (22kDa) (Pereira et al., 2015).

\subsection{FTIR}

The amide I regions $\left(1600-1700 \mathrm{~cm}^{-1}\right)$ is considered a better predictor due to $\mathrm{C}=\mathrm{O}$ stretching vibration of the protein backbone with minor support from C-N stretching (Grdadolnik, 2002). The analysis resolved bands have been assigned according to Byler \& Susi (1986). The curve-fitting results of the original spectrum is showed in Table S2, Supplementary material. The $\beta$-sheet and $\beta$-turn structures appeared to be the dominant conformation in most of the fractions. In SCP globulin the $\beta$-sheet structures $(55 \%)$ were significantly higher $(\mathrm{p}<0.05)$ than the $\beta$-turn structures (15.6\%). However, in LCP globulin the $\beta$-turn structures $(69.5 \%)$ were significantly higher $(\mathrm{p}<0.05)$ than the $\beta$-sheet structures (18.3\%). Peaks consisting of $\alpha$ - helix and random coils were detected at various proportions in the different amadumbe protein fractions.

Globulins from monocotyledonous plants are reported to contain low levels of $\alpha$ - helix and high levels of $\beta$-sheet structures (Ellopola et al., 2005). In this study, the higher content of $\beta$-sheet conformations to the $\alpha$-helix contents in the globular proteins could be due to rigidity, making the $\alpha$-type proteins more surface active than the $\beta$-type and might be useful in gelation (Gosa \& Ross-Murphy, 2000).

\subsection{Surface Hydrophobicity $\left(\mathrm{H}_{0}\right)$}

Surface hydrophobicity reveals the degree of exposure of hydrophobic groups on protein molecule surfaces and how it is linked to its interfacial activity (Liu et al., 2018). In Figure 2, the $\mathrm{H}_{0}$ values of SCW albumin and globulin were 235.20 and 270.40, which were considerably lower $(\mathrm{p}<0.05)$ than SCP albumin $(830.46)$ and globulin (925.50), respectively. These results correlate with the protein solubility (Figure 3 ) results whereby SCW albumin and globulin had higher protein solubility values than SCP albumin and globulin. High protein solubilities are attributed 
to low $\mathrm{H}_{0}$ values which could be due to lower conformational changes and less exposure of internal hydrophobic groups on the surface of protein molecules (Gong et al., 2016).

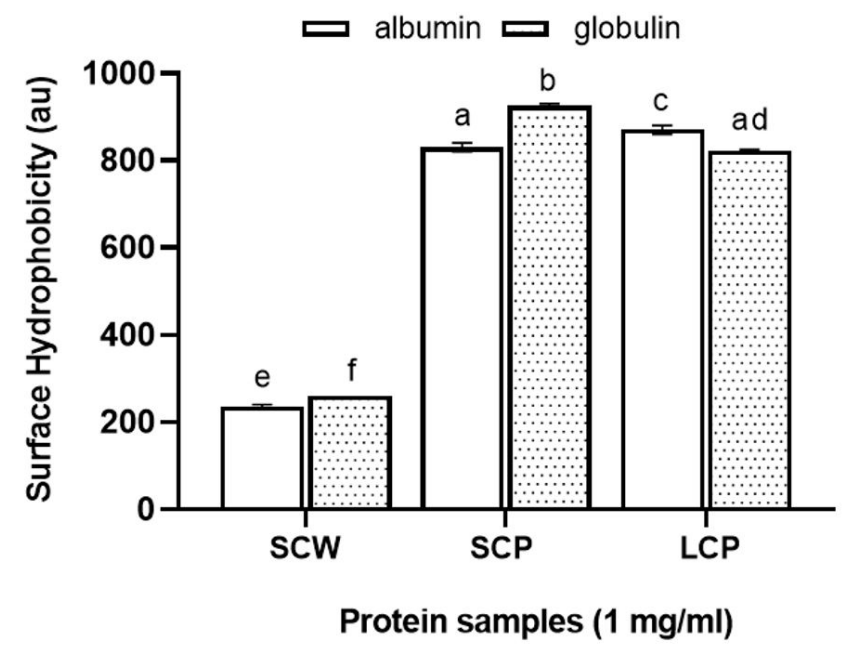

Figure 2. Surface hydrophobicity of amadumbe albumin and globulin in $10 \mathrm{mM}$ phosphate buffer (pH 7.0). Small Corm with White flesh (SCW); Small Corm with Purple flesh (SCP); Large Corm with Purple flesh (LCP). Bars with dissimilar letters are significantly $(\mathrm{p}<0.05)$ different.
The $\mathrm{H}_{0}$ values of LCP albumin and globulin were 871.22 and 822.35 which, was also consistent with the protein solubility (Figure 3 ) data. The difference in $\mathrm{H}_{0}$ values could also possibly be attributed to the distribution of amino acids existing in the protein fractions. Nwachukwu \& Aluko (2019) reported that high levels of hydrophobic amino acids in flaxseed globulins were linked to the high levels of $\mathrm{H}_{0}$ when compared to albumin. Generally, proteins with high $\mathrm{H}_{0}$ may have a greater tendency to adsorb at air-water interfaces, and therefore, exhibit high foaming and emulsifying capacities (Wouters et al., 2018), which could make amadumbe globulin fractions a good source for food product applications.

\subsection{Intrinsic fluorescence spectra}

Intrinsic fluorescence spectrum is mainly dependent on the capability of aromatic amino acids (tryptophan, tyrosine, and phenylalanine) absorbing incident light from the ultraviolet region and emitting fluorescence. Hence, intrinsic fluorescence might consequently provide useful information on the tertiary structure of proteins (Li et al., 2013).

The data shows a characteristic fluorescence profile of tryptophan (Fig. S2a, b and c, Supplementary material). The maximum emission spectrum of SCW albumin and LCP globulin suggest that the tryptophan residues could be in a more hydrophilic
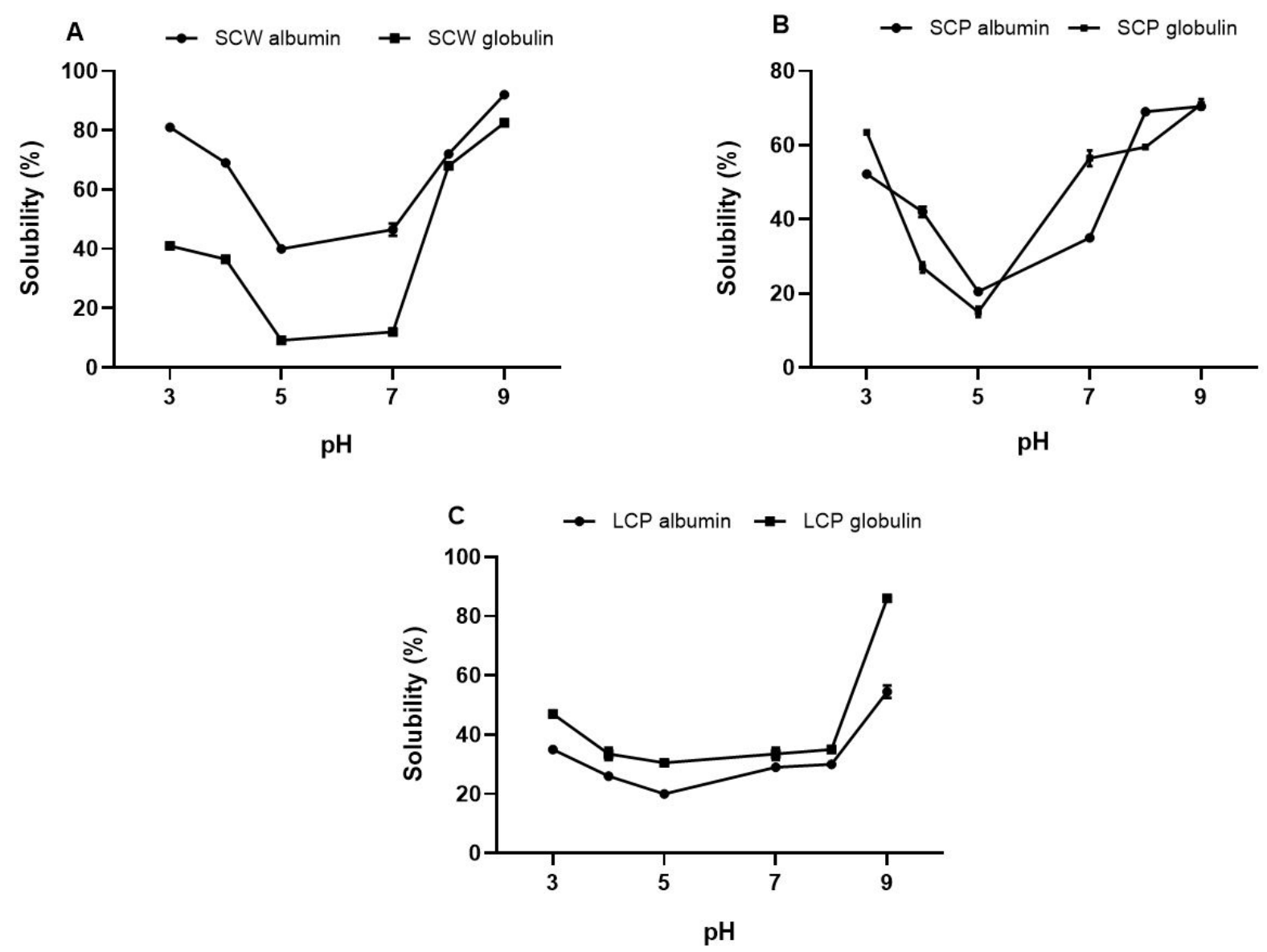

Figure 3. Effect of $\mathrm{pH}$ on protein solubility of amadumbe albumin and globulin. (A) Small Corm with White flesh (SCW); (B) Small Corm with Purple flesh (SCP); (C) Large Corm with Purple flesh (LCP). Data represents mean \pm SD. 
A

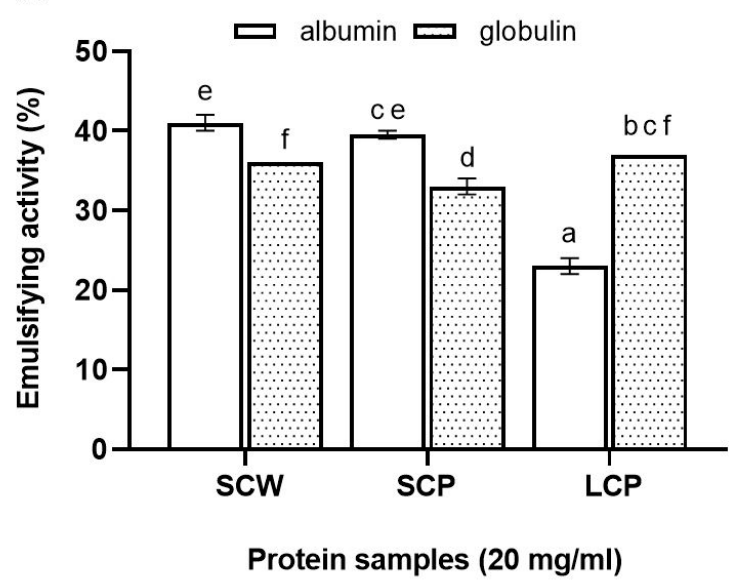

B

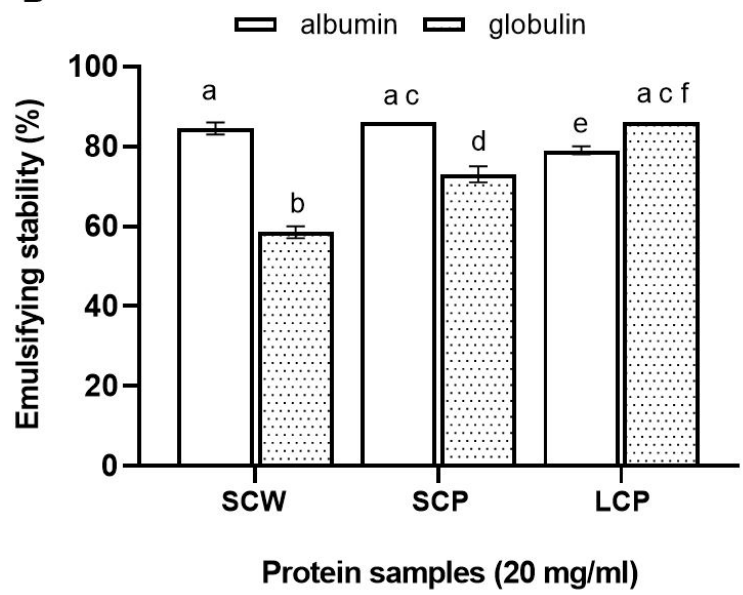

Figure 4. Emulsification properties of amadumbe albumin and globulin. (A) Emulsification activity (EA); (B) Emulsification stability (ES). Small Corm with White flesh (SCW); Small Corm with Purple flesh (SCP); Large Corm with Purple flesh (LCP). Bars with dissimilar letters are significantly $(\mathrm{p}<0.05)$ different.

environment and having a less compact structure as appose to fractions from SCP, LCP albumin and SCW globulin being in a native state. When proteins are in a native state tryptophan are buried within the core of the protein and is in a hydrophobic environment giving a high fluorescence intensity whereas, in an unfolded state they are more exposed (Suryaprakash et al., 2000). Tryptophan in SCP and LCP albumin were more exposed and closer to the protein surface than its globulin. The differences in SCP albumin and globulin fluorescence intensities could also be attributed to having different amino acid profiles.

\subsection{Protein solubility}

The protein solubility profiles of amadumbe albumin and globulin fractions increased with increasing $\mathrm{pH}$, following a U-shape trend (Figure 3). The albumin and globulin fractions showed minimal solubility at $\mathrm{pH} 5$, and this could be attributed to an increase in protein-protein interactions near its isoelectric point. SCW albumin and globulin showed maximum solubilities of $92 \%$ and $83 \%$ at $\mathrm{pH} 9$. SCP albumin and globulin had similar maximum solubilities of $71 \%$ at $\mathrm{pH} 9$.

Malomo \& Aluko (2015) demonstrated that the high protein solubility values of hemp seed albumin agreed with low values of hydrophobic and aromatic amino acids with that of hemp seed globulin. Liu et al. (2018) reported that cashew nut albumin and globulin fractions had minimal solubility at $\mathrm{pH} 3$ and 5 with maximal solubilities at $96.55 \%$ and $94.65 \%$. However, in this study the LCP albumin and globulin showed maximal solubility values of $55 \%$ and $86 \%$ at $\mathrm{pH} 9$, respectively. These results correlate with the surface hydrophobicity (Figure 2) results obtained. The results indicate that albumin and globulin fractions are highly soluble at low and high $\mathrm{pH}$. It could be attributed to its net positive and net negative charges at high acidic and alkaline regions, leading to an electrostatic repulsive force and therefore an increase in solubility (Hu et al., 2018). Amadumbe albumin and globulin fractions shows great potential to enhance its utilisation in protein beverages, food additives and different food applications.

\subsection{Emulsification properties}

The emulsification activity (EA) of amadumbe albumin and globulin fractions are represented in Figure 4a. The EA of SCW albumin and globulin were $41 \%$ and $36 \%$ while SCP albumin and globulin had an EA of $40 \%$ and 33\%, respectively. However, the EA of LCP albumin were $23 \%$ and its globulin $37 \%$. These results are directly related to the surface hydrophobicity (Figure 2) and protein solubility (Figure 3 ) results. The protein interactions with the oil droplets could have been enhanced due to the exposure of aromatic groups and therefore enabling higher oil droplet surface coverage caused by the unfolded proteins of increased surface hydrophobicity (Chao \& Aluko, 2018). Moure et al. (2002) found that emulsifying properties can mutually or solely be related to its surface hydrophobicity and solubility.

In general, the results presented a high emulsion stability (ES) in all the amadumbe albumin and globulin fractions (Figure 4b). A good emulsifier is distinguished by the ability of a proteins net charge to promptly reorient to the interface and defining its molecular elasticity (Lam et al., 2018). The amadumbe albumin and globulin fractions showed good emulsifying properties and could be a suitable emulsifier in ice cream, soup powders and processed meat products.

\section{Conclusion}

Amadumbe is a good source of lysine and leucine. The albumin and globulin seem to display good surface hydrophobicity, intrinsic fluorescence, and emulsification properties. The results indicated that amadumbe albumin and globulin fractions could be a good source of protein ingredient for food processing applications and nutraceutical ingredients, meanwhile supplying valuable information for the growth and utilisation of amadumbe in South Africa. 


\section{Conflict of interest}

The authors affirm that there is no irreconcilable interest concerned to this publication.

\section{Acknowledgements}

Authors are grateful for the financial support by the National Research Foundation (NRF, Grand No. UID 106651 and 93796), Agricultural Research Council of South Africa (ARC) which is part of the ARC/UFS/DUT collaborative consortium, (ARC-BROADENING THE FOOD BASE GRANT). The authors are thankful to Prof Suren Singh for financial support and $\mathrm{Mr}$ Melvin Makolomakwa for technical support that made certain experiments possible.

\section{References}

Adebiyi, A. P., \& Aluko, R. E. (2011). Functional properties of protein fractions obtained from commercial yellow field pea (Pisum sativum L.) seed protein isolate. Food Chemistry, 128(4), 902-908. http:// dx.doi.org/10.1016/j.foodchem.2011.03.116.

Alcantara, R. M., Hurtada, W. A., \& Dizon, E. I. (2013). The nutritional value and phytochemical components of taro (Colocasia esculenta (L.) Schott) powder and its selected processed foods. Journal of Nutrition \& Food Sciences, 3(3), 1000207. http://dx.doi.org/10.4172/21559600.1000207.

Arise, A. K., Amonsou, E. O., \& Ijabadeniyi, O. A. (2015). Influence of extraction methods on functional properties of protein concentrates prepared from South African Bambara groundnut landraces. International Journal of Food Science \& Technology, 50(5), 10951101. http://dx.doi.org/10.1111/ijfs.12746.

Association of Official Analytical Chemists - AOAC. (2000). Official methods of analysis of Association of Official Analytical Chemists (17th ed.). Rockville: AOAC.

Bidlingmeyer, B. A., Cohen, S. A., \& Tarvin, T. L. (1984). Rapid analysis of amino acids using pre-column derivatization. Journal of Chromatography. B, Biomedical Sciences and Applications, 336(1), 93-104. http://dx.doi.org/10.1016/S0378-4347(00)85133-6.

Bradford, M. M. (1976). A rapid and sensitive method for the quantitation of microgram quantities of protein utilizing the principle of proteindye binding. Analytical Biochemistry, 72(1-2), 248-254. http://dx.doi. org/10.1016/0003-2697(76)90527-3. PMid:942051.

Byler, D. M., \& Susi, H. (1986). Examination of the secondary structure of proteins by deconvolved FTIR spectra. Biopolymers, 25(3), 469487. http://dx.doi.org/10.1002/bip.360250307. PMid:3697478.

Carneiro, M., Rodrigues, C. A., Castro, L. A. B., Silva, M. C., \& Coutinho, M. V. (1990). Isolation characterization of the major albumin from Colocasia esculenta corms. Plant Science, 67(1), 39-46. http://dx.doi. org/10.1016/0168-9452(90)90048-S.

Chandrasekara, A., \& Kumar, T. J. (2016). Roots and tuber crops as functional foods: a review on phytochemical constituents and their potential health benefits. International Journal of Food Science, 2016(3), 3631647. http://dx.doi.org/10.1155/2016/3631647. PMid:27127779.

Chao, D., \& Aluko, R. E. (2018). Modification of the structural, emulsifying, and foaming properties of an isolated pea protein by thermal pre-treatment. CYTA: Journal of Food, 16(1), 357-366. http://dx.doi.org/10.1080/19476337.2017.1406536.

Costa, J. N., Brito, S. A., Leal, A. R., Rodrigues, D. C., Nascimento, L. G. L., Figueiredo, R. W., Mata, P., \& Sousa, P. H. M. (2020). Sensory characteristics of structured guava (Psidium guajava): comparison of optimized descriptive profile, cata and sensory acceptance methods. Food Science and Technology, 40(Suppl. 2), 496-502. http://dx.doi. org/10.1590/fst.25819.

Ellepola, S. W., Choi, S. M., \& Ma, C. Y. (2005). Conformational study of globulin from rice (Oryza Sativa) seeds by Fourier-Transform infrared sectroscopy. International Journal of Biological Macromolecules, 37(1-2), 12-20. http://dx.doi.org/10.1016/j.ijbiomac.2005.07.008. PMid:16140371.

Food and Agriculture Organisation - FAO, World Health Organisation WHO, United Nations University - UNU (2007). Expert Consultation on protein and amino acid requirements in human nutrition: report of a joint $\mathrm{FAO} / \mathrm{WHO} / \mathrm{UNU}$ expert consultation. Retrieved from https:// apps.who.int/iris/handle/10665/43411.

Gong, K. J., Shi, A. M., Liu, H. Z., Liu, L., Hu, H., Adhikari, B., \& Wang, Q. (2016). Emulsifying properties and structure changes of spray and freeze-dried peanut protein isolate. Journal of Food Engineering, 170, 33-40. http://dx.doi.org/10.1016/j.jfoodeng.2015.09.011.

Gosal, W. B., \& Ross-Murphy, S. B. (2000). Globular protein gelation. Current Opinion in Colloid \& Interface Science, 5(3-4), 188-194. http://dx.doi.org/10.1016/S1359-0294(00)00057-1.

Grdadolnik, J. (2002). An attenuated total reflection infrared spectroscopy of water solutions. International Journal Vibrational Spectroscopy, 6(2), 2-6.

Hayakawa, S., \& Nakai, S. (1985). Relationships of hydrophobicity and net charge to the solubility of milk and soy proteins. Journal of Food Science, 50(2), 486-491. http://dx.doi.org/10.1111/j.1365-2621.1985. tb13433.x.

Hu, G., Zhao, Y., Gao, Q., Wang, X., Zhang, J., Peng, X., Tanokura, M., \& Xue, Y. (2018). Functional properties of chinese yam (Dioscorea opposita Thunb. cv. Baiyu) soluble protein. Journal of Food Science and Technology, 55(1), 381-388. http://dx.doi.org/10.1007/s13197017-2948-2. PMid:29358831.

Ju, D., Mu, T., \& Sun, H. (2017). Sweet potato and potato residual flours as potential nutritional and healthy food material. Journal of Integrative Agriculture, 16(11), 2632-2645.

Laemmli, U. K. (1970). Cleavage of structural proteins during the assembly of the head of bacteriophage T4. Nature, 227(5259), 680685. http://dx.doi.org/10.1038/227680a0. PMid:5432063.

Lam, A. C. Y., Karaca, A. C., Tyler, R. T., \& Nickerson, M. T. (2018). Pea protein isolates: structure, extraction, and functionality. Food Reviews International, 34(2), 126-147. http://dx.doi.org/10.1080/8 7559129.2016 .1242135 .

Li, F., Wu, X., Zhao, T., Li, F., Zhao, J., \& Yang, L. (2013). Extraction, physicochemical and functional properties of proteins from milk thistle Silybum Marianum L. gaernt seeds. International Journal of Food Properties, 16(8), 1750-1763. http://dx.doi.org/10.1080/1094 2912.2011.608176.

Liu, C., Peng, Q., Zhong, J., Liu, W., Zhong, Y., \& Wang, F. (2018). Molecular and functional properties of protein fractions and isolate from cashew nut (Anacardium occidentale L.). Molecules, 23(2), 393. PMid:29439533.

Long, G., Ji, Y., Pan, H., Sun, Z., Li, Y., \& Qin, G. (2015). Characterization of thermal denaturation structure and morphology of soy glycinin by FTIR and SEM. International Journal of Food Properties, 18(4), 763-774. http://dx.doi.org/10.1080/10942912.2014.908206.

Malomo, S. A., \& Aluko, R. E. (2015). A comparative study of the structural and functional properties of isolated hemp seed (Cannabis sativa L.) albumin and globulin fractions. Food Hydrocolloids, 43, 743-752. http://dx.doi.org/10.1016/j.foodhyd.2014.08.001. 
Mawoyo, B., Adebola, P., Gerrano, A. S., \& Amonsou, E. O. (2017). Effect of genotypes and growth locations on composition and functional properties of amadumbe flour. Journal Food Science Technology, 54(2), 1-10.

Mbofung, C. M. F., Aboubakar, Y. N. N., Bouba, A. A., \& Balaam, F. (2006). Physicochemical and functional properties of six varieties of taro (Colocasia esculenta (L.) Schott) flour. Journal Food Technology, 4(2), 135-146.

Moure, A., Rua, M., Sineiro, J., \& Dominguez, H. (2002). Aqueous extraction and membrane isolation of protein from defatted Geviuna Avellane. Journal of Food Science, 67(2), 688-696. http://dx.doi. org/10.1111/j.1365-2621.2002.tb10660.x.

Nascimento, R. Q., Tavares, P. P. L. G., Meireles, S., Anjos, E. A., Andrade, R. B., MacHado, B. A. S., Souza, A. L. C., \& Mamede, M. E. O. (2020). Study on the sensory acceptance and check all that apply of mixed juices in distinct Brazilian regions. Food Science and Technology, 40(Suppl. 2), 708-717. http://dx.doi.org/10.1590/fst.37619.

Neto, V. Q., Narain, N., Silva, J. B., \& Bora, P. S. (2001). Functional properties of raw and heat processed cashew nut (Anacardium occidentale, L.) kernel protein isolates. Food Nahrung, 45(4), 258-262. http://dx.doi.org/10.1002/1521-3803(20010801)45:4<258::AIDFOOD258>3.0.CO;2-3. PMid:11534465.

Nwachukwu, I. D., \& Aluko, R. E. (2019). Structural and functional properties of food protein-derived antioxidant peptides. Journal of Food Biochemistry, 43(1), e12761. http://dx.doi.org/10.1111/ jfbc.12761. PMid:31353492.

Pereira, P. R., Aguila, E. M. D., Vericimo, M. A., Zingali, R. B., Paschoalin, V. M. F., \& Silva, J. T. (2014). Purification and characterization of the lectin from taro (Colocasia esculenta) and its effect on mouse splenocyte proliferation in vitro and in vivo. The Protein Journal, 33(1), 92-99. http://dx.doi.org/10.1007/s10930-013-9541-y. PMid:24395119.

Pereira, P. R., Correa, A. C. N. T. F., Vericimo, A., \& Paschoalin, V. M. F. (2018). Tarin a Potential Immunomodulator and COX-Inhibitor Lectin found in Taro (Colocasia esculenta). Comprehensive Reviews in Food Science and Food Safety, 17(4), 878-891. http://dx.doi. org/10.1111/1541-4337.12358. PMid:32313515.

Pereira, P. R., Silva, J. T., Vericimo, M. A., Paschoalin, V. M. F., \& Teixeira, G. A. P. B. (2015). Crude extract from taro (Colocasia esculenta) as a natural source of bioactive proteins able to stimulate haematopoietic cells in two murine models. Journal of Functional Foods, 18(A), 333-343. http://dx.doi.org/10.1016/j.jff.2015.07.014.

Shewry, P. R. (2003). Tuber storage proteins. Annals of Botany, 91(7), 755-769. http://dx.doi.org/10.1093/aob/mcg084.

Suryaprakash, P., Kumar, R. P., \& Prakash, V. (2000). Thermodynamics of interaction of caffeic acid and quinic acid with multi-subunit proteins. International Journal of Biological Macromolecules, 27(3), 219-228. http://dx.doi.org/10.1016/S0141-8130(00)00119-7. PMid:10828368.

Tattiyakul, J., Asavasaksakul, S., \& Pradipasena, P. (2006). Chemical and physical properties of flour extracted from Taro Colocasia esculenta (L.) schott grown in different regions of Thailand. Science Asia, 32(3), 279-284. http://dx.doi.org/10.2306/scienceasia1513-1874.2006.32.279.

Wouters, A. G. B., Rombouts, I., Fierens, E., Brijs, K., Blecker, C., Delcour, J. A., \& Murray, B. S. (2018). Foaming and air-water interfacial characteristics of solutions containing both gluten hydrolysate and egg white protein. Food Hydrocolloids, 77, 176-186. http://dx.doi. org/10.1016/j.foodhyd.2017.09.033. 


\section{Supplementary Material}

Supplementary material accompanies this paper.

Table S1 Albumin and globulin protein yield.

Table S2 Secondary structure band assignment (\%) of amadumbe protein fractions.

Fig. S1 Amadumbe landraces. Small corm with white flesh (SCW), small corm with purple flesh (SCP) and large corm with purple flesh (LCP).

Fig. S2 Fluorescence spectra of amadumbe albumin and globulin. A: small corm with white flesh (SCW), B: small corm with purple flesh (SCP) and C: large corm with purple flesh (LCP). Data represents mean \pm SD.

This material is available as part of the online article from http://www.scielo.br/CTA. 